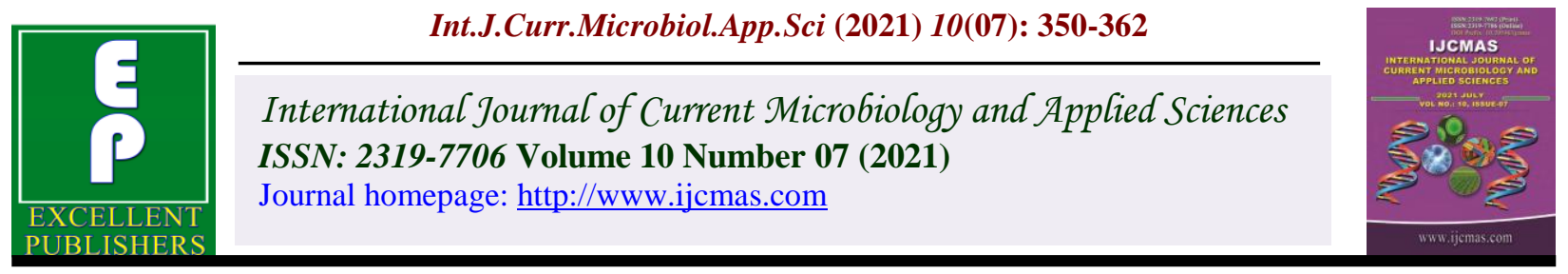

Original Research Article

https://doi.org/10.20546/ijcmas.2021.1007.038

\title{
Response of Integrated Nutrient Management on Growth and Yield Attributes of Onion (Allium cepa L.) cv. N-53
}

\author{
Harmeet Kaur* and Harpreet Kaur
}
Campus for Research and Advanced Studies Dhablan, General Shivdev Singh Diwan Gurbachan Singh, Khalsa College Patiala, 147001, India
*Corresponding author

\begin{abstract}
A B S T R A C T
Keywords

INM,

Growth and

Yield

Article Info

Accepted:

15 June 2021

Available Online:

10 July 2021

The present investigation entitled "Response of integrated nutrient management on growth and yield attributes of onion (Allium cepa L.) cv. N-53" was carried out during the year 2019-2020 in Rabi season at the Campus for Research and Advanced Studies Dhablan, G.S.S.D.G.S Khalsa College, Patiala. The growth parameters viz., maximum plant height (25.17, 54.33 and $59.87 \mathrm{~cm})$, number of leaves plant $^{-1}(9.23,10.68$ and 13.93) leaf length $(23.37,50.17$ and $55.56 \mathrm{~cm})$ were recorded with treatment $\mathrm{T}_{10}(75 \%$ $\mathrm{RDF}+\mathrm{VC} @ 1.5 \mathrm{t} \mathrm{ha}^{-1}+$ Azotobacter $)$ at 30, 60 and 90 DAT respectively. In the yield attributes, maximum length of bulb $(6.89 \mathrm{~cm})$, neck thickness $(1.68 \mathrm{~cm})$ and bulb diameter $(6.63 \mathrm{~cm})$ were recorded with same treatment at 90 DAT.
\end{abstract}

\section{Introduction}

Onion (Allium cepa L.) is one of the important commercial bulb crop belonging to the family Alliaceae having chromosome number $2 n=16$. It is one of the commercial vegetable grown in India and its place of origin is Central Asia. Onion is considered to be the second most important vegetable crop grown in the world after tomatoes. It is a rapidly growing short duration crop having multiple uses such as vegetables, spices and medicinal. It is one of the commonest and indispensable vegetable cum condiment crops grown for local consumption, export and processing (Brar et al., 2015). Onion is known as "Queen of Kitchen" due to its high flavour, fragrance and unique taste. The pungency of the onion is due to a volatile compound 'allyl-propyldisulphide' (Yadav et al., 2015). Onion contains carbohydrate $(11.0 \mathrm{~g})$, proteins (1.2 $\mathrm{g})$, fibre $(0.6 \mathrm{~g})$, moisture $(86.8 \mathrm{~g})$ and several vitamins like vitamin $\mathrm{A}(0.01 \mathrm{mg})$, vitamin $\mathrm{C}$ $(11 \mathrm{mg})$, thiamine $(0.08 \mathrm{mg})$, riboflavin $(0.01$ $\mathrm{mg}$ ) and niacin $(0.2 \mathrm{mg})$. It also contains some minerals like phosphorus (39 mg), calcium (27 $\mathrm{mg})$, sodium $(1.0 \mathrm{mg})$ and potassium $(157 \mathrm{mg})$ per $100 \mathrm{~g}$ of bulb (Sharma et al., 2018). 
In recent years, it has been appreciated that combined applications of nutrients are required for the higher yield and better quality of onion. Under the favourable agro- climatic conditions, management of the nutrients is the major factor. In modern agriculture, it is possible to produce higher yields with good quality bulbs. Onion needs the application of inorganic fertilizers for the vegetative and reproductive growth. However, a chemical fertilizer affects the soil health, flora-fauna and increases the soil acidity or alkalinity.

Inorganic fertilizers being very expensive are difficult for small and marginal farmers to afford (Shah et al., 2019).

Integrated nutrient management reduces the price of manufacturing through usage of natural wastes or its by-products in opposition to chemical fertilizers, which can be stated to supply pollutants until they are used in fertile and efficient way. Organic substances along with poultry manure, vermicompost and farm yard manure can complement inorganic fertilizers to maintain productivity and natural quality (Tripathy et al., 2017).

The farmyard manure supply nitrogen, phosphorus and potassium and other essential nutrients in available form to the plants through biological decomposition. It improves the physical, chemical and biological properties of soil such as organic matter content, microbial activities, aggregation, aeration and water holding capacity and available nutrients. Vermicomposting is a mixture of worm casting, organic materials and living earthworms. It is slow releasing organic manure, have most of the macro and micro nutrients that fulfil the nutrient requirement of plants (Gebremichael et al., 2017).

Vermicompost adds organic matter to the soil and enhances microbial activities thus enriches the soil rhizosphere and plant system with nutrients (Patidar et al., 2017). Poultry manure is the organic waste from poultry composed of mainly faeces and urine of chickens. Poultry litter is rich in many plant nutrients like $\mathrm{N}, \mathrm{P}, \mathrm{K}$ and some trace elements such as $\mathrm{Zn}, \mathrm{Cu}$, As. Biofertilizers are the products that contain living cells of different types of microorganisms; play an important role in atmospheric nitrogen fixation, phosphorus solubilisation and have an ability to convert complex forms of elements to available forms through biological process and improve the crop yield (Singh and Singh 2018). NPK fertilizers are the chemical fertilizers required by plant for rapid growth. Nitrogen being the major component of chlorophyll, proteins, enzymes, nucleic acids accelerates the plant growth and is also required by plants in greater quantities (Yohannes et al., 2013). Phosphorus (P) is major component of nucleic acids, enzymes and phospholipids and is needed for energy transfer within plant system. Phosphorus has a positive effect on early root enlargement (Singh et al., 2019). Potassium (K) plays a vital role in plant metabolic activities such as photosynthesis, translocation of metabolites, activation of various enzymes and pest-disease resistance (Singh and Singh 2017).

\section{Materials and Methods}

The experiment was conductedat Campus for Research and Advanced Studies, Dhablan, G.S.S.D.G.S Khalsa College, Patiala, during rabi season 2019-2020.The soil of experimental field was clay in texture with $\mathrm{pH}$ 7.3 , organic carbon $(0.52 \%)$, low in available nitrogen $\left(262.64 \mathrm{~kg} \mathrm{ha}^{-1}\right)$, medium in available phosphorus $\left(22.6 \mathrm{~kg} \mathrm{ha}^{-1}\right)$ and medium in available potassium (129 $\left.\mathrm{kg} \mathrm{ha}{ }^{-1}\right)$. The experiment was laid out in randomized block design (RBD) with eleven treatments and three replications. Treatment details along with the symbols used are given as: $\mathrm{T}_{1}$ : Control, $\mathrm{T}_{2}: 100 \%$ RDF 100:50:50 kg ha ${ }^{-1}, \mathrm{~T}_{3}$ : FYM@20 tha ${ }^{-1}, \mathrm{~T}_{4}: \mathrm{VC} @ 6 \mathrm{tha}^{-1}, \mathrm{~T}_{5}: \mathrm{PM}$ 
@ $3 \mathrm{t} \mathrm{ha}^{-1}, \mathrm{~T}_{6}: 75 \% \mathrm{RDF}+\mathrm{FYM} @ 5 \mathrm{t} \mathrm{ha}^{-1}$, $\mathrm{T}_{7}: 75 \% \mathrm{RDF}+\mathrm{VC} @ 1.5 \mathrm{t} \mathrm{ha}^{-1}, \mathrm{~T}_{8}: 75 \%$ $\mathrm{RDF}+\mathrm{PM} @ 0.75 \mathrm{t} \mathrm{ha}^{-1}, \mathrm{~T}_{9}: 75 \% \mathrm{RDF}+$ FYM @ $5 \mathrm{t} \mathrm{ha}^{-1}+$ Azotobacter, $\mathrm{T}_{10}: 75 \% \mathrm{RDF}$ + VC@1.5 t ha ${ }^{-1}+$ Azotobacter, $\mathrm{T}_{11}: 75 \%$ $\mathrm{RDF}+\mathrm{PM} @ 0.75 \mathrm{t} \mathrm{ha}^{-1}+$ Azotobacter.The gross and net plot sizes were $2.80 \mathrm{~m} \times 2.80 \mathrm{~m}$ and $2.50 \mathrm{~m} \times 2.50 \mathrm{~m}$ respectively. The onion was planting at spacing of $15 \times 7.5 \mathrm{~cm}$.

\section{Results and Discussion}

The results obtain from the present investigation on the Response of Integrated Nutrient Management on Growth and Yield Attributes of Onion (Allium cepa L.) cv. N-53.

\section{Growth parameters}

In the study of all the growth parameters viz., maximum plant height, number of leaves plant $^{-1}$ and leaf length were recorded at the different stages i.e. 30, 60 and 90 DAT. Analysis of variance showed that plant height was highly influenced by the combined application of organic manure and inorganic fertilizers presented in Table. 1 and graphically represented in Fig.1. The highest plant height at 30, 60 and 90 DAT $(25.17,54.33$ and 59.87 respectively) were recorded from $\mathrm{T}_{10}$ which was followed by $T_{11}$. On the other hand, least plant height $(46.15 \mathrm{~cm})$ was noted from control. This may be due to application of chemical fertilizers in combination with organic manures and bio-fertilizers at different levels increase the growth parameters. Poultry manure is a good source of both macro and micro nutrients and it can increase soil carbon, nitrogen content, soil porosity and enhance soil microbial activity. With fertilizer application, plant attained optimum growth and development due to increase in cell size and enhancement in cell division. Azotobacter play role in fixing atmospheric nitrogen and synthesis growth promoting substances. The response of integrated nutrient management on highest plant height was also revealed by
(Bagali et al., 2012) and (Jayathilake et al., 2003).

Among the different types of and levels of fertilizers, application of vermicompost in combination with chemical fertilizers $\left(\mathrm{T}_{10}\right)$ recorded the maximum number of leaves plant $^{-1}$ with 13.93 leaves at 90 days after transplanting (Table 2). This treatment was followed by $\mathrm{T}_{11}$ (75\% RDF + PM @ $0.75 \mathrm{t} \mathrm{ha}^{-}$ ${ }^{1}+$ Azotobacter). The lowest number of leaves plant $^{-1}$ was recorded with control (9.63).

The production of greater number of leaves can be due to higher metabolic activity because of the higher availability of all the essential nutrients from poultry manure and nitrogen from inorganic fertilizer resulting in higher production of carbohydrates. Biofertilizers fixed the atmospheric nitrogen which enhanced the availability of nutrients at appropriate time. Increase in number of leaves, might have result in increased photosynthetic rate. Similar result had also been found by (Gebremichael et al., 2017) and (Eragegowda et al., 2018).

The application of 75\% RDF + VC @ $1.5 \mathrm{tha}^{-}$ ${ }^{1}+$ Azotobacter increased leaf length. The data on leaf length of onion recorded at 30,60 and 90 DAT is given in Table 3 and depicted graphically in Fig. 3. It was clear from the data that highest leaf length $(\mathrm{cm})$ were recorded at 30, 60 and 90 DAT $(23.37,50.17$ and 55.56 respectively) in the treatment $\mathrm{T}_{10}$ (75\% RDF + VC @ $1.5 \mathrm{t} \mathrm{ha}^{-1}+$ Azotobacter $)$. The combined use of all the applications had great impact on the leaf length of onion.

Nitrogen and phosphorus significantly affected leaf length of onion plants. The positive effect of nitrogen on leaf length may be due to its role in chlorophyll, enzymes and protein synthesis. $\mathrm{N}$ is major constituent of proteins and due to the present of abundant protein tends to increase the size of leaves. 
Table.1 Response of integrated nutrient management on plant height (cm) of onion (Allium cepa L.)

\begin{tabular}{|c|c|c|c|}
\hline \multirow[t]{2}{*}{ Treatments } & \multicolumn{3}{|c|}{ Plant height $(\mathrm{cm})$} \\
\hline & 30 DAT & 60 DAT & 90 DAT \\
\hline $\mathbf{T}_{1}$ : Control & 16.70 & 39.12 & 46.15 \\
\hline $\mathrm{T}_{2}: 100 \%$ RDF 100:50:50 $\mathrm{kg} \mathrm{ha}^{-1}$ & 20.43 & 50.28 & 54.87 \\
\hline T $_{3}:$ FYM @ 20 tha $^{-1}$ & 17.21 & 40.55 & 48.22 \\
\hline $\mathrm{T}_{4}: \mathrm{VC} @ 6 \mathrm{tha}^{-1}$ & 18.25 & 45.68 & 51.28 \\
\hline$T_{5}:$ PM @ 3 t ha $^{-1}$ & 17.54 & 43.48 & 49.81 \\
\hline $\mathrm{T}_{6}: 75 \%$ RDF + FYM @ $5 \mathrm{t} \mathrm{ha}^{-1}$ & 18.98 & 46.92 & 53.59 \\
\hline $\mathrm{T}_{7}: 75 \% \mathrm{RDF}+\mathrm{VC} @ 1.5 \mathrm{t} \mathrm{ha}^{-1}$ & 22.68 & 51.40 & 55.34 \\
\hline $\mathrm{T}_{8}: 75 \% \mathrm{RDF}+\mathrm{PM} @ 0.75 \mathrm{tha}^{-1}$ & 21.89 & 51.10 & 55.10 \\
\hline T9: 75\% RDF + FYM @ $5 \mathrm{t} \mathrm{ha}^{-1}+$ Azotobacter & 19.48 & 48.43 & 54.48 \\
\hline $\mathrm{T}_{10}: 75 \% \mathrm{RDF}+\mathrm{VC} @ 1.5 \mathrm{t} \mathrm{ha}^{-1}+$ Azotobacter & 25.17 & 54.33 & 59.87 \\
\hline $\mathrm{T}_{11}: 75 \%$ RDF + PM @ $0.75 \mathrm{tha}^{-1}+$ Azotobacter & 23.72 & 51.82 & 56.99 \\
\hline $\begin{array}{c}\mathrm{SE}(\mathrm{d}) \pm \\
\mathrm{CD}(5 \%)\end{array}$ & $\begin{array}{l}0.77 \\
1.62\end{array}$ & $\begin{array}{l}1.35 \\
2.82\end{array}$ & $\begin{array}{l}0.68 \\
1.42\end{array}$ \\
\hline
\end{tabular}


Table.2 Response of integrated nutrient management on number of leaves plant ${ }^{-1}$ of onion (Allium cepa L.)

\begin{tabular}{|c|c|c|c|}
\hline \multirow[t]{2}{*}{ Treatments } & \multicolumn{3}{|c|}{ Number of leaves plant ${ }^{-1}$} \\
\hline & 30 DAT & 60 DAT & 90 DAT \\
\hline $\mathbf{T}_{1}:$ Control & 5.06 & 6.03 & 9.63 \\
\hline $\mathrm{T}_{2}: 100 \%$ RDF 100:50:50 kg ha ${ }^{-1}$ & 7.56 & 8.86 & 11.86 \\
\hline T $_{3}:$ FYM @ 20 t ha $^{-1}$ & 5.43 & 6.53 & 10.56 \\
\hline$T_{4}: V C @ 6 t_{h a}^{-1}$ & 6.93 & 7.33 & 11.23 \\
\hline$T_{5}:$ PM @ 3 t ha ${ }^{-1}$ & 6.73 & 6.86 & 10.63 \\
\hline $\mathrm{T}_{6}: 75 \%$ RDF + FYM @ $5 \mathrm{tha}^{-1}$ & 7.23 & 7.73 & 11.36 \\
\hline $\mathrm{T}_{7}: 75 \% \mathrm{RDF}+\mathrm{VC} @ 1.5 \mathrm{t} \mathrm{ha}^{-1}$ & 8.25 & 10.40 & 13.55 \\
\hline $\mathrm{T}_{8}: 75 \%$ RDF + PM @ $0.75 \mathrm{tha}^{-1}$ & 8.15 & 10.22 & 12.45 \\
\hline T9: 75\% RDF + FYM @ $5 \mathrm{t} \mathrm{ha}^{-1}+$ Azotobacter & 7.36 & 8.66 & 11.47 \\
\hline $\mathrm{T}_{10}: 75 \% \mathrm{RDF}+\mathrm{VC} @ 1.5 \mathrm{tha}^{-1}+$ Azotobacter & 9.23 & 11.16 & 13.93 \\
\hline $\mathrm{T}_{11}: 75 \% \mathrm{RDF}+\mathrm{PM} @ 0.75 \mathrm{t} \mathrm{ha}^{-1}+$ Azotobacter & 8.85 & 10.68 & 13.73 \\
\hline $\begin{array}{c}\mathrm{SE}(\mathrm{d}) \pm \\
\mathrm{CD}(5 \%)\end{array}$ & $\begin{array}{l}0.24 \\
0.51\end{array}$ & $\begin{array}{l}0.24 \\
0.50\end{array}$ & $\begin{array}{l}0.12 \\
0.25\end{array}$ \\
\hline
\end{tabular}


Table.3 Response of integrated nutrient management on leaf length $(\mathrm{cm})$ of onion (Allium cepa L.)

\begin{tabular}{|c|c|c|c|}
\hline \multirow[t]{2}{*}{ Treatments } & \multicolumn{3}{|c|}{ Leaf length $(\mathrm{cm})$} \\
\hline & 30 DAT & 60 DAT & 90 DAT \\
\hline $\mathbf{T}_{1}$ : Control & 12.36 & 36.34 & 40.14 \\
\hline $\mathrm{T}_{2}: 100 \%$ RDF 100:50:50 $\mathrm{kg} \mathrm{ha}^{-1}$ & 18.26 & 47.33 & 52.86 \\
\hline $\mathrm{T}_{3}:$ FYM @ $20 \mathrm{t} \mathrm{ha}^{-1}$ & 13.21 & 38.46 & 43.38 \\
\hline $\mathrm{T}_{4}: \mathrm{VC} @ 6 \mathrm{tha}^{-1}$ & 16.19 & 42.63 & 47.12 \\
\hline $\mathbf{T}_{5}:$ PM @ 3 t ha $^{-1}$ & 15.21 & 40.53 & 45.53 \\
\hline $\mathrm{T}_{6}: 75 \% \mathrm{RDF}+\mathrm{FYM} @ 5 \mathrm{tha}^{-1}$ & 16.48 & 44.57 & 48.13 \\
\hline $\mathrm{T}_{7}: 75 \% \mathrm{RDF}+\mathrm{VC} @ 1.5 \mathrm{t} \mathrm{ha}^{-1}$ & 21.99 & 47.56 & 53.87 \\
\hline $\mathrm{T}_{8}: 75 \% \mathrm{RDF}+\mathrm{PM} @ 0.75 \mathrm{t} \mathrm{ha}^{-1}$ & 21.81 & 47.49 & 53.45 \\
\hline T9: 75\% RDF + FYM @ 5 t ha $^{-1}+$ Azotobacter & 18.26 & 46.24 & 51.56 \\
\hline $\mathrm{T}_{10}: 75 \% \mathrm{RDF}+\mathrm{VC} @ 1.5 \mathrm{tha}^{-1}+$ Azotobacter & 23.37 & 50.17 & 55.56 \\
\hline $\mathrm{T}_{11}: 75 \% \mathrm{RDF}+\mathrm{PM} @ 0.75 \mathrm{t} \mathrm{ha}^{-1}+$ Azotobacter & 22.90 & 48.35 & 54.13 \\
\hline $\begin{array}{c}\mathrm{SE}(\mathrm{d}) \pm \\
\mathrm{CD}(5 \%)\end{array}$ & $\begin{array}{l}0.24 \\
0.51\end{array}$ & $\begin{array}{l}0.91 \\
1.90\end{array}$ & $\begin{array}{l}0.52 \\
1.10\end{array}$ \\
\hline
\end{tabular}


Table.4 Response of integrated nutrient management on length of bulb, neck thickness and bulb diameter (cm) of onion (Allium cepa L.).

\begin{tabular}{|c|c|c|c|}
\hline Treatments & Length of bulb (cm) & Neck thickness (cm) & Bulb diameter $(\mathbf{c m})$ \\
\hline $\mathbf{T}_{1}$ : Control & 4.05 & 1.08 & 4.11 \\
\hline $\mathrm{T}_{3}:$ FYM @ $20 \mathrm{t} \mathrm{ha}^{-1}$ & 4.53 & 1.21 & 4.66 \\
\hline T $_{5}:$ PM @ 3 t ha $^{-1}$ & 4.74 & 1.28 & 4.89 \\
\hline $\mathrm{T}_{6}: 75 \% \mathrm{RDF}+\mathrm{FYM} @ 5 \mathrm{tha}^{-1}$ & 5.24 & 1.36 & 5.13 \\
\hline $\mathrm{T}_{7}: 75 \% \mathrm{RDF}+\mathrm{VC} @ 1.5 \mathrm{t} \mathrm{ha}^{-1}$ & 6.28 & 1.60 & 6.36 \\
\hline T9: 75\% RDF + FYM @ 5 t ha $^{-1}+$ Azotobacter & 5.64 & 1.41 & 5.14 \\
\hline $\mathrm{T}_{10}: 75 \% \mathrm{RDF}+\mathrm{VC} @ 1.5 \mathrm{t} \mathrm{ha}^{-1}+$ Azotobacter & 6.89 & 1.68 & 6.63 \\
\hline $\mathrm{T}_{11}: 75 \% \mathrm{RDF}+\mathrm{PM} @ 0.75 \mathrm{t} \mathrm{ha}^{-1}+$ Azotobacter & 6.56 & 1.61 & 6.56 \\
\hline $\begin{array}{c}\mathrm{SE}(\mathrm{d}) \pm \\
\mathrm{CD}(5 \%)\end{array}$ & $\begin{array}{l}0.25 \\
0.52\end{array}$ & $\begin{array}{c}0.063 \\
0.13\end{array}$ & $\begin{array}{l}\text { 0.047 } \\
0.097\end{array}$ \\
\hline
\end{tabular}


Fig.1 Response of Integrated Nutrient Management on Plant Height $(\mathrm{cm})$ of Onion

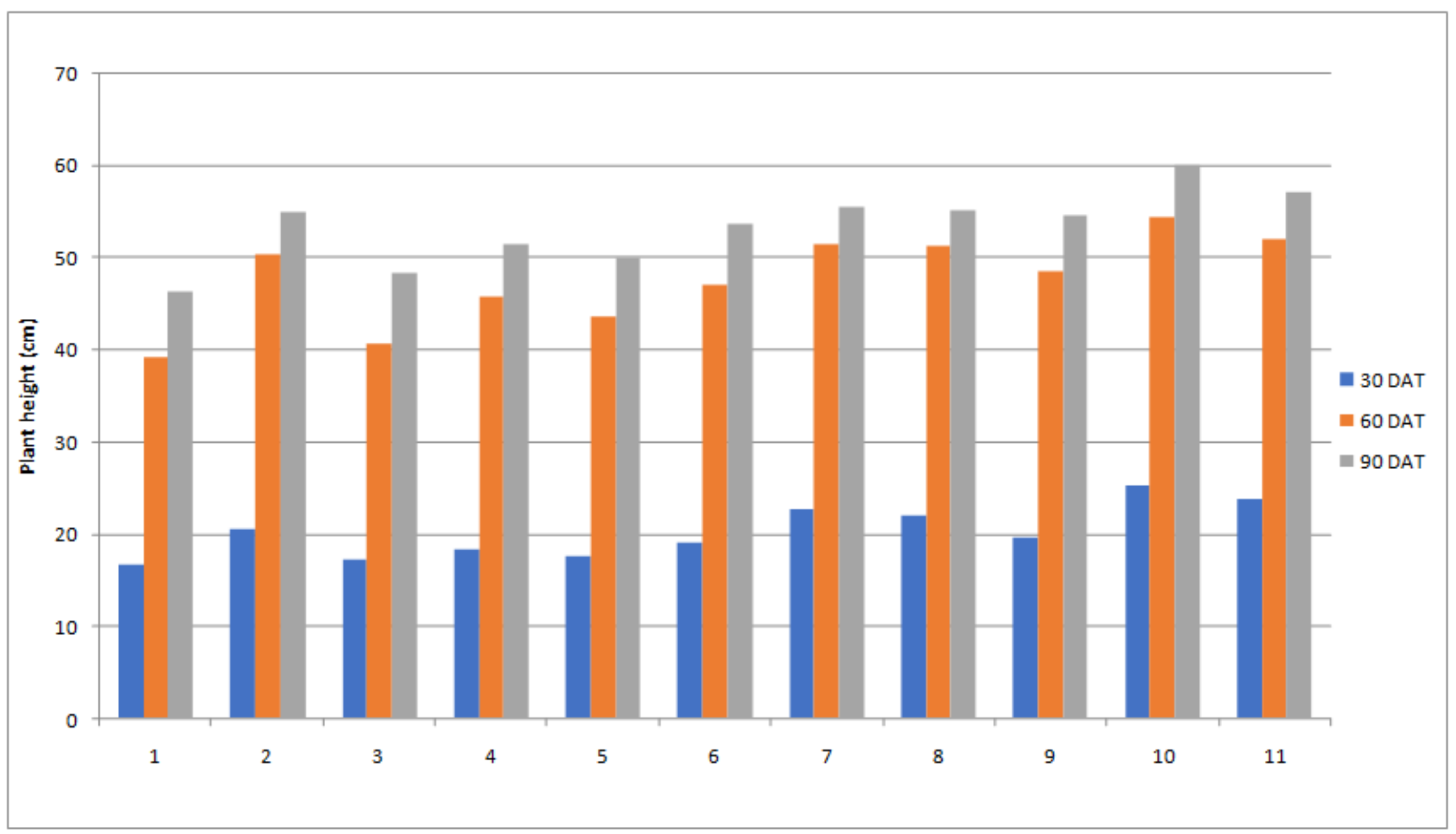


Fig.2 Response of integrated Nutrient Management on the number of leaves plant ${ }^{-1}$ of onion

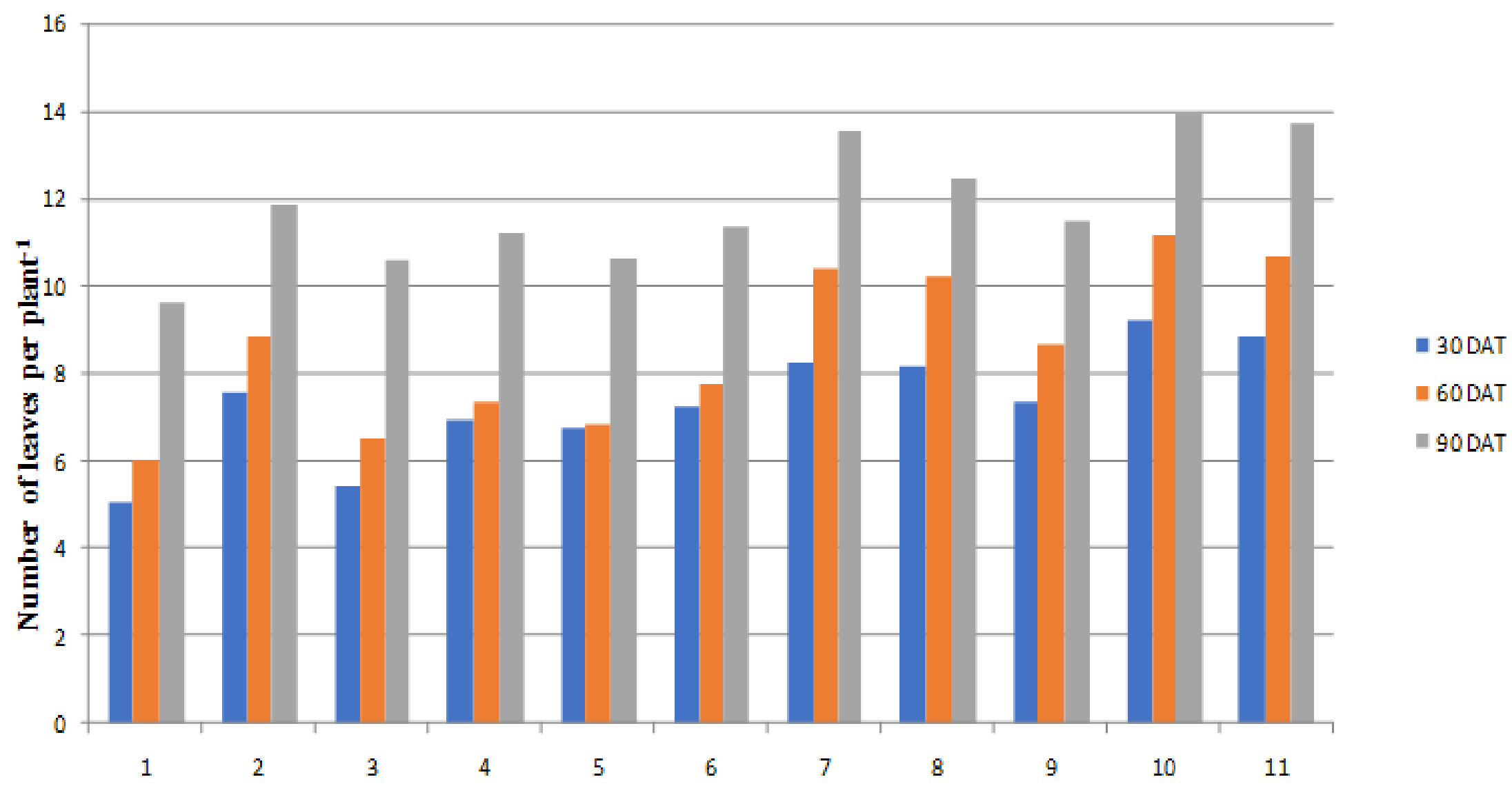


Fig.3 Response of Integrated Nutrient Management on leaf length $(\mathrm{cm})$ of onion

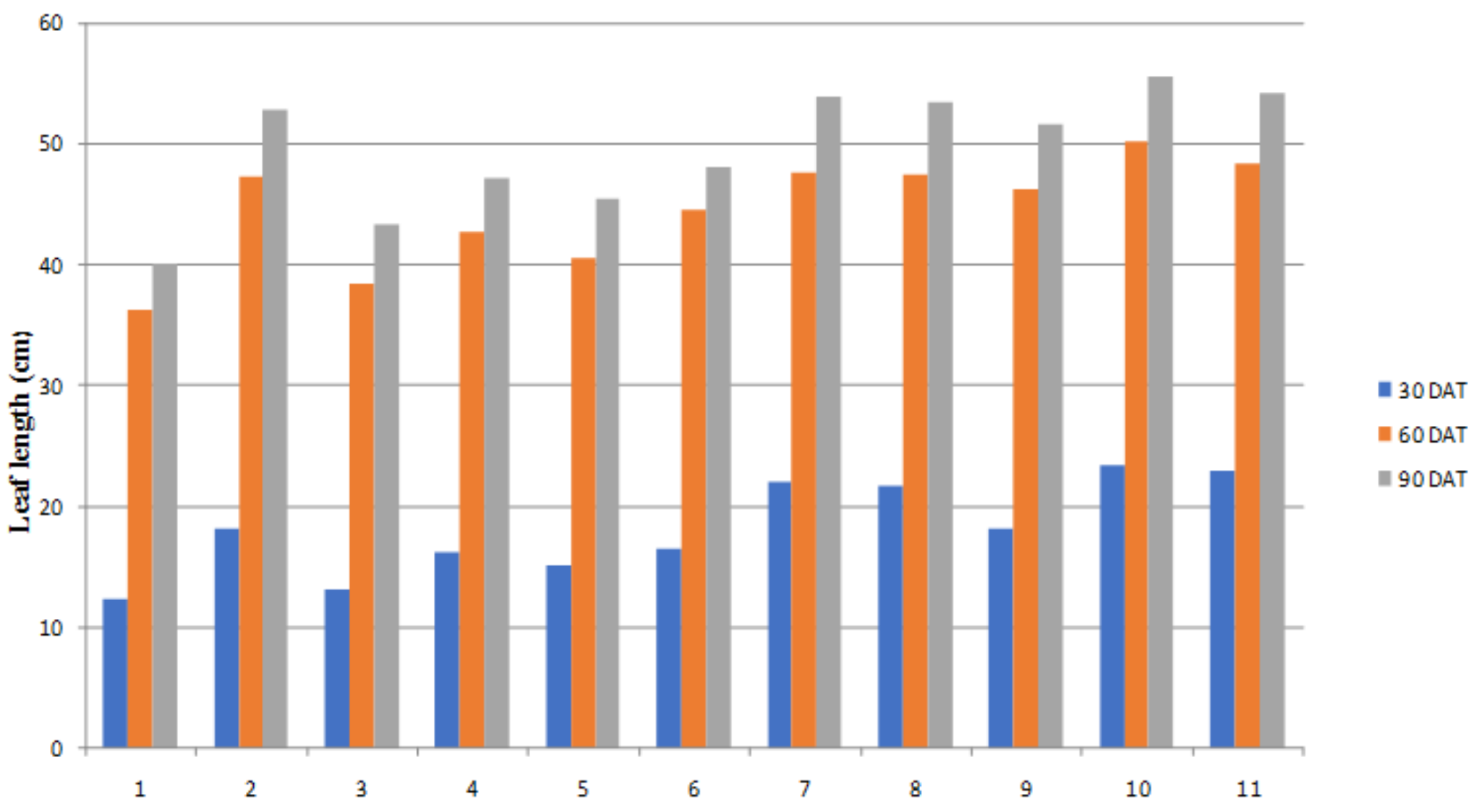


Fig.4 Response of Integrated Nutrient Management on bulb length, neck thickness and bulb diameter (cm) of onion

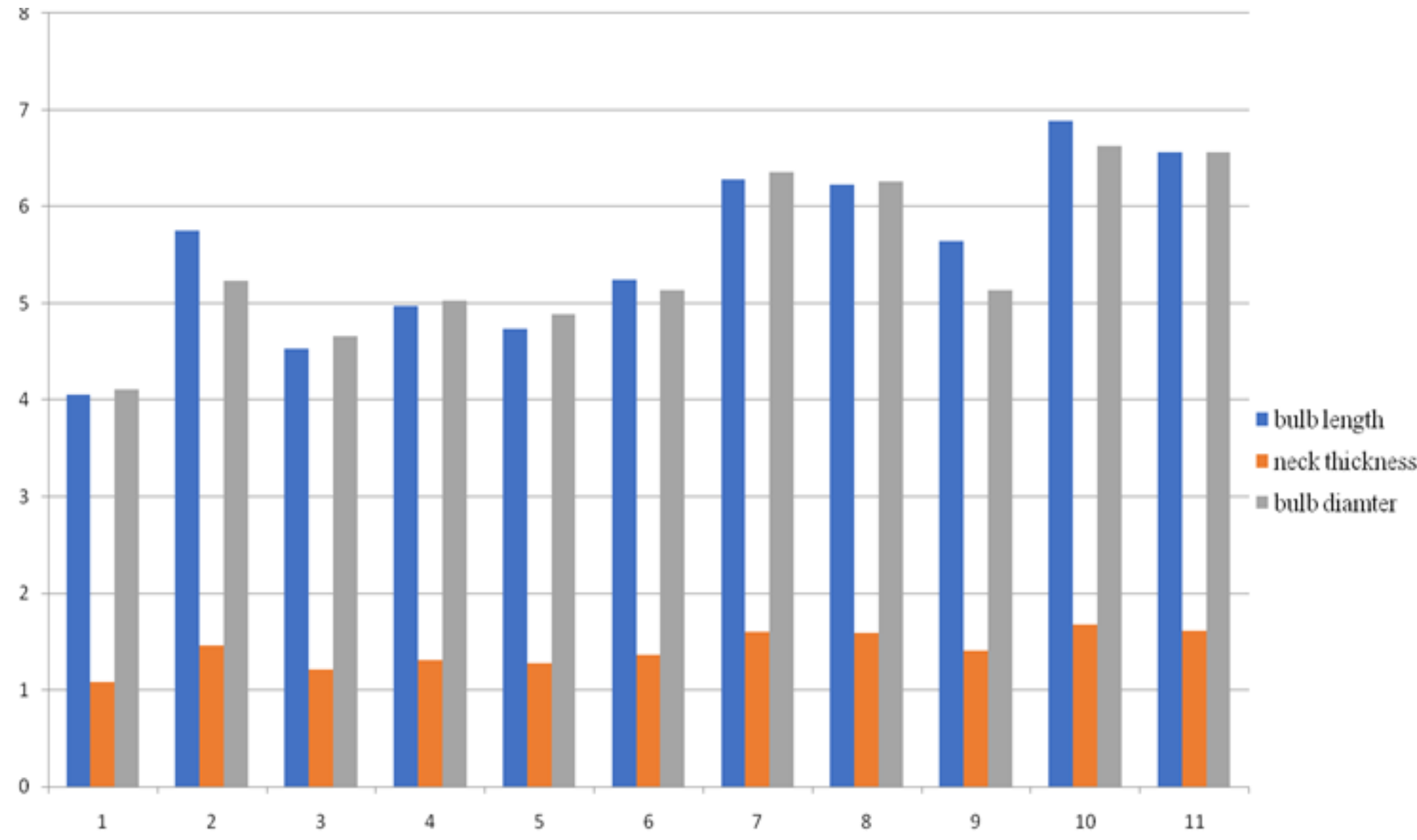


The application of poultry manure and inorganic fertilizers provide excellent effect on leaf length. These similar findings were also reported by (Tekeste et al., 2018), (Gebremichael et al., 2017) and (Shah et al., 2019).

\section{Yield attributes}

Integrated application of organic and inorganic sources highly significant variations in respect of bulb length of onion is depicted in Table 4 and depicted in Fig.4. The highest bulb length $(6.89 \mathrm{~cm})$ was achieved from $\mathrm{T}_{10}$ : $75 \% \mathrm{RDF}+\mathrm{VC} @ 1.5 \mathrm{t} \mathrm{ha}^{-1}+$ Azotobacter. The integration of organic and inorganic fertilizers supplied the necessary requirements for the proper vegetative growth of plant that helps in obtaining the maximum bulb length. The use of poultry manure increased the amount of starch and carbohydrates because of sufficient nutrients available in manure. Micronutrients enhanced the photosynthesis and other metabolic activity, which leads to increase in cell division and elongation. A similar result on length of bulb were also found by (Singh et al., 2015) and (Magdi et al., 2009).

The data pertaining to the neck thickness of bulb as significantly influenced by different integrated nutrient management treatments are presented in Table 4 and graphically depicted in Fig. 4. It is clearly indicated that the maximum neck thickness of onion $(1.68 \mathrm{~cm})$ was recorded at harvest in the treatment $T_{10}$. The treatment $T_{11}$ was followed by treatment $\mathrm{T}_{10}$. Neck thickness is one of the important growth parameter which indicated the vigour and extended growth of plant was significantly influenced by levels of inorganic fertilizers. Due to the major nutrients supplied by the inorganic fertilizers would be utilized quickly by the crop and all other macro and micro nutrients available in organic manures would be released slowly. The combination of these manures helped to increase the availability of major nutrients which is being the constituent of protein and protoplasm, vigorously inducing the vegetative development of the plants. These results were also corroborated with the findings of Yadav et al., (2015).

The data pertaining to diameter of bulb recorded under different treatments are presented in Table 4 and graphically depicted in Fig. 4. The diameter of bulb showed significant differences for different treatments. The maximum bulb diameter of onion (6.63 $\mathrm{cm})$ was recorded at harvest in the treatment $\mathrm{T}_{10} \quad\left(75 \% \mathrm{RDF}+\mathrm{VC} @ 1.5 \mathrm{t} \mathrm{ha}^{-1}+\right.$ Azotobacter). The minimum diameter of bulb $(4.11 \mathrm{~cm})$ was found under the treatment $T_{1}$ (control) at harvest. The combined use of biofertilizers with inorganic fertilizers increased the growth promoting substances. The availability of atmospheric nitrogen and soil phosphorus which might have led to luxuriant bulb size. Phosphorus helps in reproductive growth and also involved in cell enlargement that result in increased the diameter of bulb. One of the reasons might be more accumulation of carbohydrates resulting into increased diameter of bulb, which is the storage organ. Similar results had also been found by Singh and Singh (2017).

\section{References}

Bagali AN, Patil HB, Chimmad VP, Patil PL and Patil RV. 2012. Effect of inorganics and organics on growth and yield of onion (Allium cepa L.). Karnataka Journal of Agriculture Science. 25(1):112-115.

Brar RK, Sharma R and Kaur J. 2015.Effect of organic source of nutrients on yield and quality of onion (Allium cepa L.).Indian Journal of Ecology. 42(1):266-277.

Eragegowda M, Venkatesha J, Hiremath JS, Mahantesh DS, Ravi Y and Manjesh GN. 2018. Effect of integrated nutrient management on growth and yield of garlic
(Allium
сера
L.). Journal 
pharmacognosy and phytochemistry. SP3. 387-389.

Gebremichael Y, Woldetsadik K, Chavhan A and Gedamu F. 2017.Effect of integrated nutrient management on growth and bulb yield of onion under irrigation at Selekleka.International Journal of Life Sciences. 5(2):151-160.

Jayathilake PKS, Reddy IP, Srihari D, Reddy KR and Neeraja G. 2003.Integrated Nutrient management in Onion (Allium cepa L.).Tropical Agricultural Research. 15:1-9.

Magdi AAM and Mohamed FM. 2009. Enhanced yield and quality of onion (Allium cepa L.) cv Giza 6 produced using organic fertilization. Assiut University Bulletin for Environmental Researches. 12(1): 9-14.

Patidar M, Shaktawat RPS and Naruka IS. 2017. Effect of sulphur and vermicompost on growth, yield and quality of garlic (Allium Sativum L.). Journal of KrishiVigyan.5(2):54-56.

Shah KN, Chaudhary IJ, Rana DK and Singh V. 2019.Impact assessment of different organic manures on growth, morphology and yield of onion (Allium cepa L.).Asian Journal of Agricultural Research. 13(1): 20-27.

Singh G, Kumar R, Singh S and Thakur KS. 2019. Effect of integrated nutrient management on some growth characteristics of onion (Allium cepa L.). Journal of Pharmacognosy and Phytochemistry. 553-556.

Singh S, Verma D, Singh H, Singh N and Singh V. 2015.Integrated nutrient management on higher yield, quality and profitability of onion (Allium cepa L.). Indian Journal of Agricultural Sciences. 85(9): 1214-
1218.

Singh G and Singh SK. 2017.Effect of biofertilizers and NPK on yield of garlic and nutrient management availability of soil.Agriways. 5(2): 91-96.

Singh D and Singh B. 2018.A study of integrated nutrient management on growth and yield of onion (Allium cepa L.).The Pharma Innovation Journal. 7(5):473-475.

Sharma SK, Garhwal OP, Mahala P and Yadav TV. 2018. Influence of integrated nutrient management on yield attributes and economics of kharif onion (Allium cepa L.) under loamy sand soils. International Journal of Current Microbiology and Applied Sciences.7(6):806-811.

Tekeste N, Dechassa N, Woldetsadik K, Dessalegne L and Takele A. 2018. Influence of nitrogen and phosphorus application on bulb yield and yield components of onion (Allium cepa L.) The Open Agriculture Journal. 12:194-06. Tripathy P, Sahoo BB, Patel D and Dash DK. 2017. Evaluation of integrated nutrient management modules for garlic (Allium sativum L.).Journal of Ecology and Environment. 35(1):78-83.

Yadav R, Dwivedi DH, Govind and Maji S. 2015.Effect of integrated nutrient management on growth and yield of onion (Allium cepa L.).cv. PusaMadhavi. Journal crop andWeed. 11(1):48-53.

Yohannes KW, Belew D and Debela A. 2013.Effect of farmyard manure and nitrogen fertilizer rates on growth, yield and yield components of onion (Allium cepa L.) at Jimma, Southwest Ethiopia. Asian Journal of Plant Sciences. 12(6):228-234.

\section{How to cite this article:}

Harmeet Kaur and Harpreet Kaur. 2021. Response of Integrated Nutrient Management on Growth and Yield Attributes of Onion (Allium cepa L.) cv. N-53. Int.J.Curr.Microbiol.App.Sci. 10(07): 350-362. doi: https://doi.org/10.20546/ijcmas.2021.1007.038 